\title{
Characterization of the oils from the pulp and seeds of avocado (cultivar: Fuerte) fruits
}

\author{
By Pushkar S. Bora, Narendra Narain`, Rosalynd V.M. Rocha and Marçal Queiroz Paulo
}

\author{
Departamento de Tecnología Química e de Alimentos, Universidade \\ Federal da Paraíba, 58059-900 João Pessoa-PB, Brazil. \\ e-mail: narain@funape.ufpb.br
}

\section{RESUMEN}

Caracterización de los aceites de la pulpa y semillas de aguacate (cultivar: Fuerte).

La semilla y pulpa del aguacate (Persea americana Mill), cultivar Fuerte, cultivado en la región del nordeste de Brasil fueron analizados para determinar su composición centesimal. El contenido de lípidos en pulpa y semillas, en la base húmeda fueron $15.39 \%$ y $1.87 \%$, respectivamente. Los aceites extraídos de la pulpa y de las semillas por hexano representan similares índices de refracción (1.4608 y 1.4592), densidad específica (0.9272 y 0.9300 ) e índice de peróxidos (1.40 y 1.37) pero diferentes índices de acidez (2.45 y 4.12), iodo (77.6 y 69.4) y saponificación (178.3 y 231.6), respectivamente. El análisis de cromatografía gaseosa revela la presencia de 22 y 27 ácidos grasos en aceite de pulpa y de semillas, respectivamente. El ácido palmítico fue el principal ácido saturado, presente en concentraciones de 21,3\% en pulpa y $20,8 \%$ en aceites de semillas. La principal diferencia entre estos aceites fue su contenido de ácidos grasos mono-insaturados ( $\mathrm{C}_{18: 1}-64.3 \%$ en aceite de pulpa y $15.4 \%$ de semillas) y poli-insaturado $\left(C_{18: 2}\right.$ y $C_{18: 3}-9.14 \%$ y $0.46 \%$ respectivamente, en aceite de pulpa y $34.39 \%$ y $5.81 \%$ respectivamente, en aceite de semillas).

PALABRAS-CLAVE: Aceite - Acidos grasos (composición) Aguacate - Propiedades físico-químicas.

\section{SUMMARY}

Characterization of the oils from the pulp and seeds of avocado (cultivar: Fuerte) fruits.

Avocado (Persea americana Mill) pulp and seeds of the cultivar Fuerte, cultivated in the Northeast region of Brazil, were analysed for their proximate composition. The lipid contents of the pulp and seeds were $15.39 \%$ and $1.87 \%$, respectively. Hexane extracted oils from pulp and seeds presented similar refractive indices (1.4608 and 1.4592$)$, specific gravity $(0.9272$ and 0.9300$)$ and peroxide values (1.40 and 1.37), but different acid (2.45 and 4.12 ), iodine (77.6 and 69.4) and saponification values (178.3 and $231.6)$, respectively. Gas chromatographic analysis revealed the presence of twenty two and twenty seven fatty acids in pulp and seed oils, respectively. Palmitic acid was the principal saturated acid, present in concentrations of $21.3 \%$ in pulp and $20.8 \%$ in seed oils. The major difference between these oils was in their mono-unsaturated $\left(\mathrm{C}_{18: 1}-64.3 \%\right.$, for pulp and $15.4 \%$ in seed oil) and poly-unsaturated $\left(\mathrm{C}_{18: 2}\right.$ and $\mathrm{C}_{18: 3}-9.14 \%$ and $0.46 \%$, respectively, in pulp oil and $34.39 \%$ and $5.81 \%$, respectively, in seed oil) fatty acids composition.

KEY-WORDS: Avocado - Fatty acids (composition) - Oil Physico-chemical properties.

\section{INTRODUCTION}

The avocado fruit belongs to the family of Lauraceae which includes approximately 150 species, majority of which are habitat of tropical America. The fruit distinguishes itself from other fruits due to its high lipid content and is consumed as food, and as ingredient in the formulations of pharmaceutical and cosmetic products. The oil content of the fruit depends upon its ecological origin and on the cultivar, as for example, in Guatemalan and Mexican cultivars, the oil content varies from 10 to $13 \%$ and from 15 to $25 \%$, respectively (Biale and Young 1971) while in the fruits from Carrebean, a low fat (2.5 to $5 \%$ ) has been reported (Hatton et al. 1964). According to Soares et al. (1992) adulteration of olive oil with avocado oil to a level of $35 \%$ is undetectable on the basis of flavor as the avocado oil possesses similar characteristics to that of olive oil (Gutfinger \& Letan 1974; Freitas et al. 1993). Though some work has been published on the physico-chemical properties (Tango et al. 1972), and the fatty acids composition (Mazliak 1971; Tango et al. 1972; Itoh et al. 1975, Martinez et al. 1988, Southwell et al. 1990,) of the pulp oil obtained from some important avocado cultivars, and of the seed oil (Mazliak 1971), no comparative study on the characterization of the pulp and seed oils of the fruits of the same avocado cultivar is so far available. Furthermore, the fatty acid composition of the avocado oil, besides the cultivar and stage of ripening, depends upon the geographical growth location (Ahmad and Barmore, 1980). The present work was therefore undertaken to compare the physical and physicochemical properties of the oils extracted from the pulp, and seed of the avocado (cultivar: Fuerte), fruits, as well as to compare their fatty acid composition.

\section{EXPERIMENTAL}

Preparation of the pulp and seed samples of avocado fruits: Avocado fruits (Lauraceae spp.), cultivar Fuerte were obtained from a farm located in the vicinity of the city of João Pessoa in the state of «Paraíba» in Brazil. The fruits, were stored at room temperature (approx. $28^{\circ} \mathrm{C}$ ) till they become ripe. 
The pulp and seeds were removed manually from the fruit and the pulp was homogenised in a domestic blender. The seeds were cut into small pieces and triturated in a mill. The pulp and seed samples were filled in polyethylene bags and stored in a refrigerator.

Proximate analysis of pulp and seeds: Moisture, protein, lipid, ash and, crude fibre contents were determined following the standard AOAC (1990) methods. Total carbohydrate content was calculated from the difference. Ten different samples were analysed in duplicate.

Extraction of the oil: The homogenized avocado pulp and triturated seeds were dried in an oven for 24 hours at $50^{\circ} \mathrm{C}$. The dried mass was triturated again in a mill and passed through the sieves of 40 mesh sizes. The oil was obtained by extraction of the dried powders with solvent hexane. Three lots for each oil were prepared.

Physical and physicochemical properties of oil: The specific gravity and refractive index were determined at room temperature $\left(28^{\circ} \mathrm{C}\right)$ using specific density bottle and refractometer, respectively. For determination of acid, peroxide, iodine and saponification values, standard AOAC (1990) methods were used. Three different samples of oil were analysed in duplicate.

Fatty acid composition of seed oil: Fatty acids were transformed to their methyl esters (FAME) following the method of Hartman and Lago (1973) and were determined by using a gas chromatograph HP 5890 Series III (Hewlett Packard) equipped with a flame ionisation detector. $1.5 \mu \mathrm{l}$ of the FAME sample was injected and GC separation was carried out on BP-INNOwax capillary column (Hewlett Packard; $30 \mathrm{~m}$ length, $0.25 \mathrm{~mm}$ i.d. and $0.25 \mu \mathrm{m}$ film thickness). The carrier gas (helium) head pressure was maintained at $11.5 \mathrm{psi}$ and the column flow rate was $1 \mathrm{ml} / \mathrm{min}$. The oven temperature was held initially at $120^{\circ} \mathrm{C}$ for $1 \mathrm{~min}$, later increased at $8^{\circ} \mathrm{C} / \mathrm{min}$ to $210^{\circ} \mathrm{C}$ and then maintained at $210^{\circ} \mathrm{C}$ for $45 \mathrm{~min}$. The temperatures of the injection port and of detector were $250^{\circ} \mathrm{C}$ and $280^{\circ} \mathrm{C}$, respectively. FAME were positively identified by matching their retention time data and mass spectra with those of the authentic standards obtained from various firms (Sigma; Nu-Chek-Prep, USA) which were also run under identical analytical conditions using high resolution GC-MS system (GCQ of Finnigan Mat).

\section{RESULTS AND DISCUSSION}

The proximate analysis of the avocado pulp and seeds is presented in Table I. Besides moisture, the lipid was the principal constituent of the pulp present in concentrations of nearly $15.4 \%$. For cultivar Fuerte, Tango et al. (1972) reported a higher lipid content $(22.1 \%)$, while Freitas et al. (1993) reported a recovery of $20 \%$ lipid from the pulp of the same
Table I

Proximate composition (\% w/w; average value \pm standard deviation) of the avocado pulp and seeds

\begin{tabular}{crr}
\hline Constituents (\%) & \multicolumn{1}{c}{ Pulp } & \multicolumn{1}{c}{ Seed } \\
\hline Moisture & $78.24 \pm 2.54$ & $56.04 \pm 2.58$ \\
Lipids & $15.39 \pm 1.56$ & $1.87 \pm 0.31$ \\
Protein & $1.01 \pm 0.18$ & $1.95 \pm 0.16$ \\
Ash & $0.66 \pm 0.09$ & $1.87 \pm 0.24$ \\
Fibre & $0.53 \pm 0.16$ & $5.10 \pm 1.11$ \\
Carbohydrates (by diff.) & $4.17 \pm 1.37$ & $33.17 \pm 2.73$ \\
\hline
\end{tabular}

cultivar. Lipid concentrations ranging from 15 to $30 \%$ in Fuerte, Bacon and Hass cultivars were also reported by Biale and Young (1971). In comparison with the pulp, the seeds contained only $1.87 \%$ lipids. The protein content of the pulp and seeds were 1.01 and $1.87 \%$ respectively. For California and Florida fruits, the protein content ranged from 1.21 to $2.26 \%$ as reported by Hall et al. (1955) and Slater et al. (1975). Other constituents such as ash, fibre and carbohydrates were present in smaller quantities in pulp than in the seeds.

Table II shows the data on some physical and physico-chemical properties of pulp and seed oils extracted with hexane. The refractive index, specific gravity and peroxide values of the pulp and seed oils were very close to each other. These indices/values for the pulp oil were similar to the ones reported by Soares et al (1991). However, there was a considerable difference in the saponification values of pulp and seed oils, being 178.3 and 231.6, respectively. Tango et al. (1972) reported a range of 167.6 to 190.1 for saponification value. The iodine values of the pulp (77.6) and seed (69.4) oils differed very little from the reported values of 76.5 to 99.7 for the pulp oil of different avocado cultivars (Tango et al. 1972). A high iodine value (133) for the pulp oils of Bacon, Fuerte and Hass cultivars was reported by Martinez et al. (1988).

Table II

Some physical and physico-chemical properties of avocado pulp and seed oils

\begin{tabular}{lcc}
\hline \multicolumn{1}{c}{ Characteristics } & Pulp oil & Seed oil \\
\hline Refractive Index & $1.4608 \pm 0.0004$ & $1.4592 \pm 0.0012$ \\
Specific Gravity & $0.9272 \pm 0.0028$ & $0.9300 \pm 0.0046$ \\
Acid Value & $1.23 \pm 0.02$ & $2.06 \pm 0.32$ \\
Peroxide Value & $1.40 \pm 0.215$ & $1.37 \pm 0.208$ \\
lodine Value & $77.6 \pm 1.54$ & $69.4 \pm 1.04$ \\
Saponification Value & $178.3 \pm 1.61$ & $231.6 \pm 1.40$ \\
\hline
\end{tabular}


Fatty acid composition of seed oil: The fatty acid composition of the pulp and seed oil is presented in Table III. In earlier reports (Mazliak 1971), eight fatty acids were reported in the pulp oil of cultivar Fuerte, while Southwell et al. (1990) reported the presence of only six fatty acids. However in this study, we could identify as many as 22 fatty acids in the pulp oil. A large majority of these fatty acids in the pulp oil has not been reported earlier. Only $\mathrm{C}_{16: 0}, \mathrm{C}_{16: 1}, \mathrm{C}_{18: 0}, \mathrm{C}_{18: 1}, \mathrm{C}_{18: 2}$ fatty acids (Martinez et al. 1988; Soares et al. 1991) together with $C_{18: 3}$ (Frega et al. 1990 Southwell et al. 1990) and $\mathrm{C}_{14: 0}, \mathrm{C}_{20: 0}$ in trace amounts (Mazliak, 1971) were reported in the pulp oil of different avocado cultivars. In all the cultivars $\mathrm{C}_{18: 1}$ (oleic acid) was always the principal fatty acid followed by $\mathrm{C}_{16: 0}$ (palmitic) and $\mathrm{C}_{18: 2}$ (linoleic). Other fatty acids reported to be present in trace concentrations were $\mathrm{C}_{14: 0}$ (myristic)
$\mathrm{C}_{18: 0}$ (stearic), $\mathrm{C}_{18: 3}$ (linolenic) and $\mathrm{C}_{20: 0}$ (arachidic) acids (Gutfinger and Letan, 1974, Itoh et al. 1975, Mazliak 1971, and Tango et al. 1972). Similar to these reports we also observed that the major fatty acid in the pulp oil was $C_{18: 1}$ followed by $C_{16: 0}$ and $\mathrm{C}_{18: 2}$ however, the concentrations of these fatty acids in the pulp oil were different from the cited reports. This quantitative difference is justifiable in view of the fruits from different geographical origin and other factors such as maturity and harvest practices. According to the Mazliak (1971) the concentration of the fatty acids $\mathrm{C}_{18: 1}, \mathrm{C}_{16: 0}$ and $\mathrm{C}_{18: 2}$ in the Fuerte mesocarp oil was 67-72, 13-16.7 and 10.4-11.4\%, respectively while Martinez et al. (1988) reported a range of $60-65,15-19$ and $11-12 \%$, respectively for the same fatty acids in the oil from Becon, Fuerte, and Hass cultivars. Besides, they also reported the presence of $\mathrm{C}_{16: 1}$ (palmitoleic acid) in the concentration of 7.5 to $8.6 \%$

Table III

Fatty Acid Composition of Avocado Pulp and Seed Oils

\begin{tabular}{|c|c|c|c|}
\hline \multirow{2}{*}{ Fatty Acid } & & \multicolumn{2}{|c|}{$\%$ of the total fatty acid } \\
\hline & & Pulp oil & Seed oil \\
\hline $\begin{array}{l}\text { Saturated fatty acids: } \\
\text { Hexanoic acid } \\
\text { Heptanoic acid } \\
\text { Octanoic acid } \\
\text { Nonanoic acid } \\
\text { Decanoic acid } \\
\text { Undecanoic acid } \\
\text { Dodecanoic acid } \\
\text { Tridecanoic acid } \\
\text { Tetradecanoic acid } \\
\text { Pentadecanoic acid } \\
\text { Hexadecanoic acid } \\
\text { Heptadecanoic acid } \\
\text { Octadecanoic acid } \\
\text { Nonadecanoic acid } \\
\text { Eicosanoic acid } \\
\text { Docosanoic acid } \\
\text { Tetracosanoic acid }\end{array}$ & $\begin{array}{l}\left(\mathrm{C}_{6: 0}\right) \\
\left(\mathrm{C}_{7: 0}\right) \\
\left(\mathrm{C}_{8: 0}\right) \\
\left(\mathrm{C}_{9: 0}\right) \\
\left(\mathrm{C}_{10: 0}\right) \\
\left(\mathrm{C}_{11: 0}\right) \\
\left(\mathrm{C}_{12: 0}\right) \\
\left(\mathrm{C}_{13: 0}\right) \\
\left(\mathrm{C}_{14: 0}\right) \\
\left(\mathrm{C}_{15: 0}\right) \\
\left(\mathrm{C}_{16: 0}\right) \\
\left(\mathrm{C}_{17: 0}\right) \\
\left(\mathrm{C}_{18: 0}\right) \\
\left(\mathrm{C}_{19: 0}\right) \\
\left(\mathrm{C}_{20: 0}\right) \\
\left(\mathrm{C}_{22: 0}\right) \\
\left(\mathrm{C}_{24: 0}\right)\end{array}$ & $\begin{array}{c}22.927 \\
0.12 \pm 0.064 \\
\operatorname{Tr} \\
0.075 \pm 0.015 \\
\operatorname{Tr} \\
\\
0.284 \pm 0.096 \\
\operatorname{Tr} \\
0.062 \pm 0.028 \\
21.312 \pm 0.550 \\
0.033 \pm 0.001 \\
0.762 \pm 0.021 \\
0.086 \pm 0.004 \\
\operatorname{Tr} \\
0.065 \pm 0.035\end{array}$ & $\begin{array}{c}32.495 \\
0.800 \pm 0.045 \\
0.290 \pm 0.097 \\
0.278 \pm 0.052 \\
0.217 \pm 0.006 \\
\operatorname{Tr} \\
\operatorname{Tr} \\
0.278 \pm 0.051 \\
0.166 \pm 0.011 \\
0.537 \pm 0.052 \\
2.334 \pm 0.110 \\
20.847 \pm 0.843 \\
1.725 \pm 0.022 \\
1.185 \pm 0.011 \\
0.610 \pm 0.341 \\
0.043 \pm 0.020 \\
1.114 \pm 0.023 \\
1.685 \pm 0.045\end{array}$ \\
\hline $\begin{array}{l}\text { Monounsaturated fatty acids: } \\
\text { 9-tetradecenoic acid } \\
\text { 10-pentadecenoic acid } \\
\text { 9-hexadecenoic acid } \\
\text { 10-heptadecanoic acid } \\
\text { 9-octadecenoic acid } \\
\text { 11-eicosenoic acid } \\
\text { 13-docosenoic acid }\end{array}$ & $\begin{array}{l}\left(\mathrm{C}_{14: 1}\right) \\
\left(\mathrm{C}_{15: 1}\right) \\
\left(\mathrm{C}_{16: 1}\right) \\
\left(\mathrm{C}_{17: 1}\right) \\
\left(\mathrm{C}_{18: 1}\right) \\
\left(\mathrm{C}_{20: 1}\right) \\
\left(\mathrm{C}_{22: 1}\right)\end{array}$ & $\begin{array}{c}67.433 \\
0.115 \pm 0.052 \\
0.071 \pm 0.004 \\
2.391 \pm 0.188 \\
0.106 \pm 0.004 \\
64.436 \pm 0.666 \\
0.249 \pm 0.036 \\
0.065 \pm 0.012\end{array}$ & $\begin{array}{c}20.712 \\
0.251 \pm 0.002 \\
0.321 \pm 0.159 \\
1.786 \pm 0.325 \\
0.372 \pm 0.083 \\
17.410 \pm 0.058 \\
0.448 \pm 0.277 \\
0.124 \pm 0.043\end{array}$ \\
\hline $\begin{array}{l}\text { Polyunsaturated fatty acids: } \\
\text { 9,12-octadecadienoic acid } \\
9,12,15-\text { octadecatrienoic acid } \\
\text { 11,14,17-eicosatrienoic acid } \\
\text { Unsaturated/Saturated fatty acid ratio } \\
\text { Polyunsaturated/Saturated fatty acid ratio } \\
\text { Oleic/Linoleic acid ratio }\end{array}$ & $\begin{array}{l}\left(\mathrm{C}_{18: 2}\right) \\
\left(\mathrm{C}_{18: 3}\right) \\
\left(\mathrm{C}_{20: 3}\right)\end{array}$ & $\begin{array}{c}9.614 \\
9.147 \pm 0.030 \\
0.467 \pm 0.016 \\
\\
3.36 \\
0.42 \\
7.04 \\
\end{array}$ & $\begin{array}{c}46.726 \\
38.892 \pm 0.585 \\
6.577 \pm 0.028 \\
1.257 \pm 0.030 \\
2.07 \\
1.44 \\
0.45 \\
\end{array}$ \\
\hline
\end{tabular}

* $\operatorname{Tr}$ - Traces (concentration less than $0.06 \%$ of the total fatty acids). 
against the value of 3-5. $1 \%$ reported by Mazliak (1971). However, a higher concentration (72.2\%) of $\mathrm{C}_{18: 1}$ fatty acid in avocado pulp oil was reported by Southwell et al. (1990). In our study, the principal fatty acids and their concentrations in the pulp oil were: $\mathrm{C}_{18: 1}-64.43 \%, \mathrm{C}_{16: 0}-21.31 \%$, $\mathrm{C}_{18: 2}-9.15 \%$ and $\mathrm{C}_{16: 1}-2.39 \%$ (Table III). In addition to these, $\mathrm{C}_{6: 0}, \mathrm{C}_{8: 0}, \mathrm{C}_{13: 0}, \mathrm{C}_{14: 1}, \mathrm{C}_{15: 1}, \mathrm{C}_{17: 1}, \mathrm{C}_{18: 0}, \mathrm{C}_{18: 3}$, $\mathrm{C}_{20: 0}, \mathrm{C}_{20: 1}, \mathrm{C}_{22: 1}$ and $\mathrm{C}_{24: 0}$ were present in concentrations varying from 0.06 to $0.76 \%$, and $\mathrm{C}_{7: 0}$, $\mathrm{C}_{9: 0}, \mathrm{C}_{14: 0}, \mathrm{C}_{15: 0}, \mathrm{C}_{17: 0}, \mathrm{C}_{22: 0}$ in trace quantities (less than $0.06 \%$ of the total fatty acids).

Saturated fatty acids constituted about $22.93 \%$ of the total fatty acids of the pulp oil while in the seed oil was about $32.45 \%$. All saturated fatty acids from $\mathrm{C}_{6}$ to $\mathrm{C}_{24}$ except for $\mathrm{C}_{21}$ and $\mathrm{C}_{23}$ were identified in the seed oil. The $\mathrm{C}_{16}$ fatty acid $(20.85 \%$ of total fatty acids) was also the principal saturated fatty acid of the seed oil followed by fatty acids $C_{15}, C_{17}, C_{24}, C_{18}$ and $\mathrm{C}_{22}$ which were present in concentrations of $2.33,1.72,1.68,1.18$ and $1.11 \%$ of total fatty acids, respectively. Other saturated fatty acids were present in concentrations ranging from $0.16 \%\left(\mathrm{C}_{13}\right)$ to $0.80 \%\left(C_{6}\right)$ while $\mathrm{C}_{10}, \mathrm{C}_{11}$, and $\mathrm{C}_{20}$ fatty acids were present in trace quantities.

Both the oils constituted the same monounsaturated fatty acids, but quantitatively their composition was different. Fatty acids $\mathrm{C}_{18: 1}(64.43 \%$ in pulp and $17.41 \%$ in seed oil) and $\mathrm{C}_{16: 1}(2.39 \%$ in pulp and $1.78 \%$ in seed oil) were the principal acids. Mazliak (1972) reported 67-72 \% $\mathrm{C}_{18: 1}$ and 3-5.1\% $\mathrm{C}_{16: 1}$ fatty acids in the mesocarp and $25 \% \mathrm{C}_{18: 1}$ and $3.2 \% \mathrm{C}_{16: 1}$ fatty acids in the avocado seed oil.

Avocado seed oil contained high concentrations of $\mathrm{C}_{18: 2}(38.89 \%)$ and $\mathrm{C}_{18: 3}(6.57 \%)$ fatty acids. The concentration of these fatty acids in the pulp oil was relatively low $(9.14 \%$ and $0.46 \%$, respectively). A favourable $\mathrm{C}_{18: 2} / \mathrm{C}_{18: 3}$ fatty acid ratio of the avocado seed oil could possibly be responsible for reducing the triglycerides and HDL in blood plasma as was observed by Werman et al. (1991) in a nutritional study with rats. In our study, the unsaturated to saturated fatty acids ratios were 3.36 and 2.07 and polyunsaturated to saturated fatty acids were 0.42 and 1.44 , respectively for the pulp and seed oils. However, for the pulp oil of the same cultivar, Slater et al. (1975) reported higher values for these ratios (7.4 and 0.73 , respectively). In relation to oleiclinoleic acid ratio, a parameter responsible for the shelf life of the oils, the avocado pulp oil (7.4) had a much higher ratio than the seed oil (0.447).

To detect adulteration of avocado oil with avocado seed oil, Werman et al. (1996) have reported a thin layer chromatographic method. Alternatively based on these findings, we also suggest that the concentrations of $\mathrm{C}_{18: 2}$ and $\mathrm{C}_{18: 3}$ fatty acids and their ratio (about 6 in seed oil and 18 in the pulp oil) could possibly be used for determining the authenticity of avocado oils of Fuerte cultivar.

\section{REFERENCES}

Ahmad, E. M. and Baarmore, C.R. (1982). Avocado in Tropical and Subtropical Fruits (eds. Steven Nagy and Philip E. Shaw), AVI Publishing Inc. Westport Connecticut.

AOAC (1990). Official Methods of Analysis. $15^{\text {th }}$ ed. Association of Official Analytical Chemists, Washington DC.

Biale, J. B. and Young, R. E. (1971). The avocado pear. In: "The Biochemistry of Fruits and Their Products». A.C. Hulme (ed), Academic Press, NY.

Frega, N., Bocci, F., Lercker, G. and Bortolomeazzi, R. (1990). Lipid composition of some avocado cultivars. Ita. J. Food Sci. 3, 197-204.

Freitas, S. P., Lago, R. C. A; Jablonca, F. H. and Hartman, L. (1993). Aqueous enzymic extraction of avocado oil firom fresh pulp. Revue Francaise des Corps Gras; 40(11/12), 365-371.

Gutfinger, T. and Letan, A. (1974). Studies of unsaponifiables in several vegetable oils. Lipids. 9, 658-663 (Fr)

Hartman, L. and Lago, R. C. A. (1973). Rapid preparation of fatty acid methyl esters from lipids. Laboratory Practice. 22, 475-476.

Hatton Jr., T. T., Harding, P. L. and Reeder, W. F. (1964). Seasonal changes in Florida avocados. Proc. Fla. State Hortic. Soc. 72, 349-353.

Itoh, T., Tamura, T., Matsumato, T. and. Dupaigne, P. (1975). Studies on avocado oil in particular on the unsaponifiable sterol fraction. Fruits 30, 687-695.

Mazliak, P. (1971). Avocado lipid constituents. Fruits 26, 615-623.

Martínez, N. L., Camacho, R. F., Rodriguez, V. S. and Moreno, H. M.V. (1988). Extraction and characterization of avocado oil. Grasas y Aceites, 39, 272-277.

Popenoe, W. (1920). Manual of Tropical and Subtropical Fruits. MacMillan Co. NY.

Soares, S. E., Filho, J. M., Turatti, J. M. and Tango, J. S. (1991). Caracterização Física, Química e Avaliação da Estabilidade do óleo de abacate (Persea americana Mill.) nas diferentes etapas do processo de refinação. Ver. Farm. Bioquím. Univ. S. Paulo. 27, 70-82.

Soares, S. E., Mancini Filho, J., Modesta, R. C. della. (1992). Sensory detection limits of avocado oil in mixtures with olive oil. Revista Española de Ciencia y Tecnologia de Alimentos. 32(5), 509-516.

Southwell, K. H., Harris, R. V. and Swetman, A. A. (1990). Extraction and refining of oil obtained from dried avocado fruit using a small expeller. Trop. Science. 30, 121-131.

Tango, J.S., Da Costa, S. L, Antunes, A. J. and Figueredo, L.B. (1972). Composition of fruit oil of different varieties of avocado grown in Sáo Paulo. Fruits 27, 143-146.

Werman, M. J., Neeman, I. and Mokady, S. (1991). Avocado oils and hepatic lipid metabolism in growing rats. Food and Chemical Toxicology. 29, 93-99.

Werman, M. J., Mokady, S. and Neeman, I. (1996). A simple and sensitive method for detecting avocado seed oil in various avocado oils. J. Amer. Oil Chemists Soc. 73(5), 665-667. 